\title{
A Strategic Approach to Performance Management in Banks:
}

\section{The Balanced Scorecard}

\author{
Elif Öztürk ${ }^{1} \&$ Ali Coskun ${ }^{2}$ \\ ${ }^{1}$ International Burch University, Sarajevo, Bosnia and Herzegovina \\ ${ }^{2}$ Fatih University, Istanbul, Turkey \\ Correspondence: Elif Öztürk, International Burch University, Sarajevo, Bosnia and Herzegovina
}

Received: June 2, 2014

Accepted: August 9, 2014

Online Published: August 14, 2014

doi:10.5430/afr.v3n3p151

URL: http://dx.doi.org/10.5430/afr.v3n3p151

\begin{abstract}
This paper provides the literature with a theoretical background on implementation of the balanced scorecard on strategic performance management in banking industry. The main aim of this study is to reveal the Balanced Scorecard practices in the literature. Balanced Scorecard is a strategic performance management system that brought a holistic approach to the performance measurement which is the most important activity of an administration's control function. Moreover, this study contributes to the literature with examples from the different regions of the world. Findings show that it is more beneficial to prepare the balanced scorecard for the banks than to report financial performance only in terms of evaluating performance with a holistic approach.
\end{abstract}

Keywords: Balanced scorecard, Performance management, Control function

JEL Classification Codes: M10, L25

\section{Introduction}

Performance measurement is the most important activity of a management's control function. Performance measurement can be done in a systematic way for the entire organization and it might be done temporarily or for a particular purpose. Each organization has its own distinctive reasons to do performance measurement.

Organizations usually do performance measurement to determine things, such as determining the needs of customers and seeing if they are able to fulfill their requests or not; approving their knowledge and accuracy for the activities done and finding out what they do not know; seeing if they are successful generally; making sure that the taken decisions are made with facts not with emotions or assumptions; revealing problem fields or determining fields with the development possibility (Parker, 2000).

The purpose of this paper is to contribute to the literature with presenting the balanced scorecard implementations in banks from past to present. The approach to the concept of performance has shown a change over the years. So, this study is just a small contribution to the issue.

\section{Literature Review}

In the early 1990s, the business world brought a holistic approach to the concept of performance. It's recognized as the balanced scorecard and it was an important turning point for performance management. The balanced scorecard is a worldwide accepted management accounting tool which proposed that non-financial performance measurements should also be measured with financial performance measurements, so institutional performance is measured in a multi-dimensional way which results in a better focusing on the institution's strategies. The Balanced Scorecard considers the value of intangible assets along with tangible ones and enables performance management system to reach its aims. (Kaplan and Norton, 2004 b) The BSC turns an organization's visions and strategies into actions. Through the Balanced Scorecards, institutional strategies are adopted by other organizations and the institution's internal integrity is ensured. The BSC turn the strategies set by top managers into explicit, clear and focused strategy.

Earlier studies focus on different points of performance measurements. For instance, Bikker (2010) studied on how well financial institutions perform in providing their services to customers and businesses. Moneva et al, (2010) evaluated the significance of the link between corporate environmental and financial performance in order to see the contribution of those performances to the success. Their results present the idea that higher rates of environmental performance provide a better financial performance. Additionally, service performance is one of the important 
indicators of performance management in earlier studies. Many researchers concur that service quality is important for strategic performance management (Parasuraman et al., 1985; Carman, 1990; Bolton and Drew, 1991). Firdaus et al (2011) suggest the following three dimensions of service quality: systemization, reliable communication and responsiveness. Moreover, there are also studies considering the size of banks as a main indicator for performance measurement. Al-Tamimi (2011) finds out that large banks perform better than small banks, so the most important performance indicator of that study is the bank size. Furthermore, in earlier studies researchers provide evidence to the importance of performance management and measurement to perform more successfully (Epstein \& Westbrook, 2001; Wisner, Epstein, \& Bagozzi, 2006; Davila, Epstein, \&Shelton, 2006). (Deville at al., 2014) studied on performance measurement in hierarchical organizations. Differently, there are studies showing how to implement performance measurement systems in public sector. They also present how managers use the contractibility system (Speklé, 2014). In earlier years, a lot of industry, commerce and business service sectors started to use the BSC in different countries. Earlier studies show that there are interests on implementation of Balanced Scorecard in companies (Barnabe \& Busco, 2012; Kraus \& Lind, 2010; Malina, Norreklit \& Selto, 2007; Norreklit, Mitchell, \& Bjomenak, 2012; Salterio, 2012). This new trend is especially popular for performance management process in banks. In this study, with the Balanced Scorecards, performance measurement and management is conceptually examined. Managers are required to fulfill their control function by determining the performance targets, measuring performance, comparing achieved performance with determined targets, calculating the difference of achieved performance with determined targets, and making a move by eliminating those differences. Performance measurement system should be designed to work with organizational structures and activities within the hierarchy. If performance measurement systems are going to be successful, managers should consider that as an essential part of their obligation. It should not be forgotten that the main goal of measuring performance is to increase performance. (Parker, 2000) states that performance criteria should be clear, reliable and healthy, as well as easily understood by everyone. So, the system must be designed clearly and simply, so it can be understood easily to see if the targeted performance is reached or not. At the BSC, the performance criteria associated with each other are grouped using multiple dimensions. The BSC should include financial and non-financial criteria in a single report and in a "balanced" way. Therefore, when measuring corporate performance, a balanced weight is given to performance criteria in all the dimensions of Balanced Scorecards (Horngren, Datar \& Foster, 2003). The BSC developed by Kaplan and Norton (1992), it originally has four main performance perspectives. Those performance perspectives are financial perspective, process perspective, customer perspective, and learning and growth perspective. These four perspectives of the BSC are used in most of the organizations. However, some other organizations use differently numbered and named perspectives because of the structure of the organization structure, presented product or services features. Nowadays, however, the opportunities to see the strength, speed of learning, innovation, quality, flexibility, reliability and accountability have become very important elements. Therefore, performance measurement and administration systems should be formed by considering innovations. Performance criteria can be divided into financial and non-financial. While assessing and deciding, administrators use indicators which are usually easy to measure and measuring system is already installed. The managers who usually focus on financial criteria neglect some important dimensions that are not easy to measure, but greatly affect the performance of the institution. 
Table 1. Metro Bank’s Balanced Scorecard

\begin{tabular}{|c|c|c|}
\hline Strategic Objectives & $\begin{array}{l}\text { Strategic Measurements } \\
\text { (lag indicators) }\end{array}$ & $\begin{array}{l}\text { Strategic Measurements } \\
\text { (lead indicators) }\end{array}$ \\
\hline Financial & Return-on-investments & \\
\hline Improve Returns & Revenue growth & Revenue mix \\
\hline Broaden Revenue Mix & Deposit service cost change & \\
\hline \multicolumn{3}{|l|}{ Customer } \\
\hline $\begin{array}{l}\text { Increase customer satisfaction } \\
\text { with our products and people }\end{array}$ & Share of segment & Depth of relationship \\
\hline Increase satisfaction 'after the sale` & Customer retention & Satisfaction survey \\
\hline \multicolumn{3}{|l|}{ Internal } \\
\hline \multicolumn{3}{|l|}{ Understand our customers } \\
\hline Creative Innovative products & New product revenue & Product development cycle \\
\hline Cross-sell products & Cross-sell ratio & Hours with customers \\
\hline $\begin{array}{l}\text { Shift customers to cost-effective } \\
\text { channels }\end{array}$ & Channel mix change & \\
\hline Minimize operational problems & Service error rate & \\
\hline Responsive service & Request fulfillment time & \\
\hline \multicolumn{3}{|l|}{ Learnings } \\
\hline Develop strategic skills & Employee satisfaction & Strategic job coverage ration \\
\hline Provide strategic information & & $\begin{array}{l}\text { Strategic information } \\
\text { availability ratio }\end{array}$ \\
\hline Align personal goals & Revenue per employee & Personnel goals alignment \\
\hline
\end{tabular}

Source: Kaplan and Norton, 1996a, p. 155

Instead of focusing on traditional approaches on performance measurement such as profit and productivity, nowadays Balanced Scorecard strength, speed of learning, innovation, quality, flexibility, reliability and accountability have become very important elements. Therefore, performance measurement and administration systems should be formed by considering those elements and individual or organizational performance targets are required to be designed in this way. Additionally, there are percentages of companies that perform the balanced scorecard successfully in Table 2 (Norton, 2000: 13-14).

Table 2. Balanced Scorecard weights and Norton`s Proposal

\begin{tabular}{llllll}
\hline Company Name & $\begin{array}{l}\text { Financial } \\
\text { Perspective }\end{array}$ & $\begin{array}{l}\text { Customer } \\
\text { Perspective }\end{array}$ & $\begin{array}{l}\text { Internal } \\
\text { Perspective }\end{array}$ & $\begin{array}{l}\text { Learning and } \\
\text { Growth } \\
\text { Perspective }\end{array}$ & TOTAL \\
\hline Brown \& Root & $\% 24$ & $\% 19$ & $\% 33$ & $\% 24$ & 21 \\
\hline Chemical Bank & $\% 22$ & $\% 22$ & $\% 34$ & $\% 22$ & 23 \\
\hline Cinga P\&C & $\% 17$ & $\% 26$ & $\% 35$ & $\% 22$ & 23 \\
\hline Mobil USM\&R & $\% 21$ & $\% 16$ & $\% 59$ & $\% 13$ & 24 \\
\hline Proposed by Norton & $\% 22$ & $\% 22$ & $\% 34$ & $\% 22$ & $23-25$ \\
\hline
\end{tabular}

Source: David P. Norton, "Beware: The UnBalanced Scorecard”, Balanced Scorecard Report, C: II, No: 2, 2000, s.13-14.

\section{The Balanced Scorecard for Banks}

At the end of 1999, a survey, answered by 140 managers of banks, insurance companies, and other financial institutions in the United States, showed that 20 percent of the organizations use the Balanced Scorecard. According to survey results, 11 percent of those answering the survey do the preparatory work to implement the Balanced Scorecard, 17 percent stated that they consider using the Balanced Scorecard. 51 percent of those answering the survey do not think of using the Balanced Scorecard. (Ittner, Larckerand Randall, 2003). A survey conducted in 1998 determined that nine out of 20 biggest banks in the UK use the BSC (Broady-Preston \& Preston, 1999). A survey, done in 2002 by "Bain \& Company" about "management tools and techniques" and answered by 708 business managers from various regions of 
the world, showed that 62 percent of the managers stated that they use the Balanced Scorecard (Rigby, 2003).The same research done in 1999 determined that 43, 9 percent of the managers use the Balanced Scorecard in the United States (Rigby, 2001).

Performance management can be addressed at three levels: organizational (strategic), business process and employees. (Rousseau and Rousseau, 1999: 25-29) Different Balanced Scorecards are prepared for different levels belonging to an organization, a group of individuals, or units. For instance, a business group called "General Electric Lightening" formed their Balanced Scorecards for different levels such as corporate scorecard, group scorecard, unit scorecard, factory scorecard, and employee scorecard (Davis, 1996: 14-18). (Soderberg et al., 2011) provide literature with performance measurement systems on 149 organizations and they find out that Balanced Scorecard is widely applied by organizations as a performance measurement and strategy implementation tool. On the other hand, (Antonsen, 2014) studied on downside of the BSC in Norway and the study states the way of using BSC influence interactive and personal learning and commitment of the line managers and employees in, and reduce organizational learning. Also, the results of the study showed that instant measurement does not guarantee critically reflective work behavior and has the opposite effect of absorbing valuable slack time in team meetings that otherwise could be used for reflection by advisors and line managers on improving work practices. Wua et al (2009), provide the literature with critical aspects of evaluating criteria as well as gaps to improve banking performance in order to achieve desired level and the study shows that the proposed fuzzy evaluation model of banking performance using the BSC framework can be a useful and effective assessment tool. (Zhang et al., 2009) studied the balanced scorecard in a commercial bank in the performance management system and they stated the Balanced Scorecard raises the value of performance management appraisal system based on the introduction of customer factors, internal business processes, employee learning and growth and financial factors. The following figure indicates the four indicators of commercial banks evaluation index system.

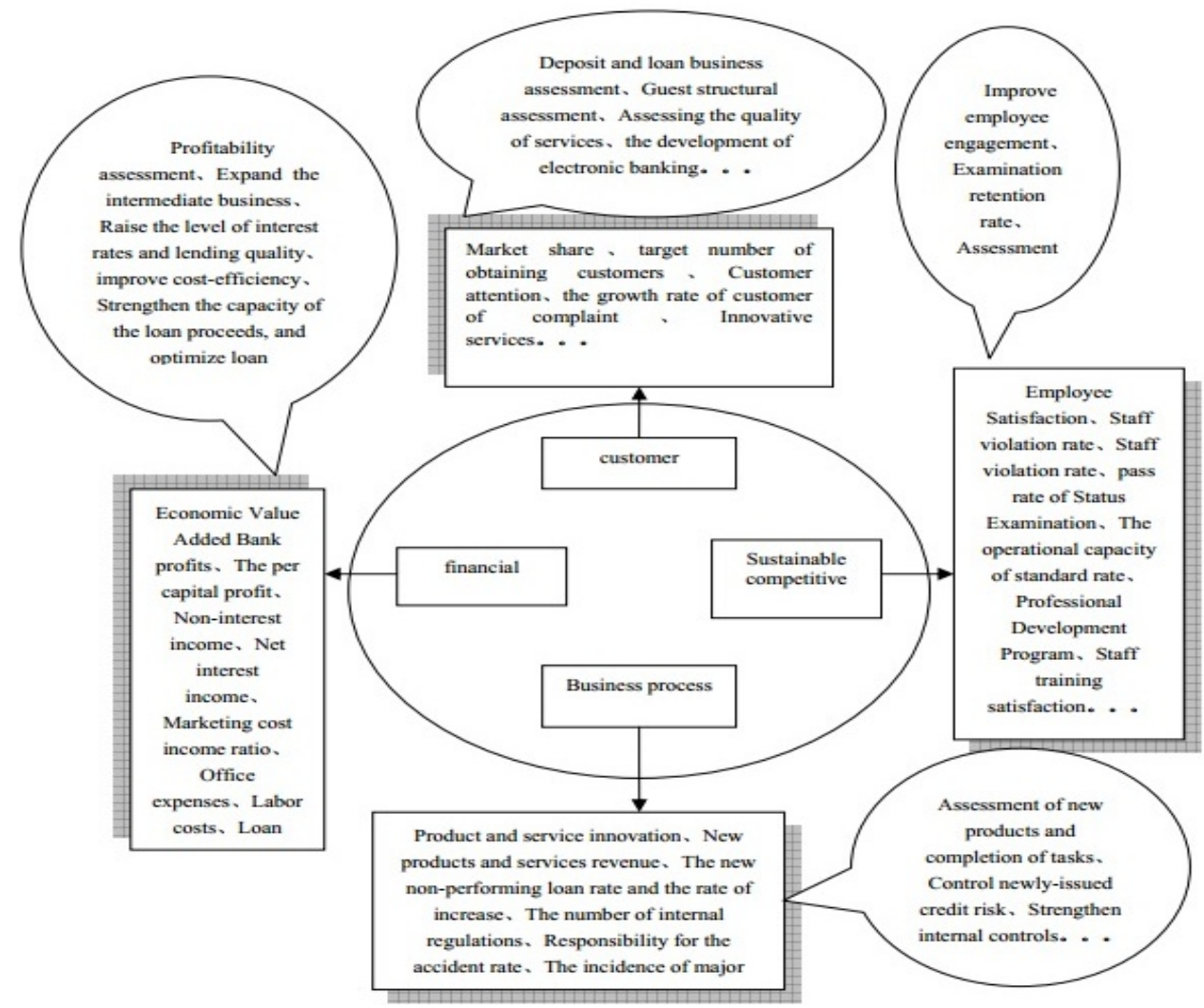

Figure 1. The four indicators of commercial banks Bank of evaluation index system

Source: Zhang and Li, 2009

As it is stated in the figure commercial banks implemented all aspects of the balanced scorecard. The structures of commercial banks are comprehensive aimed to get profit by operating financial assets in terms of the service they offer. As it is seen from the figure there should be a comprehensive approach for performance measurement that is implemented in commercial bank. What is more, the following hierarchical framework of the BSC performance 
evaluation criteria for banking is in the literature. This hierarchical framework is created by (Wu et al., 2009) and it includes the BSC performance goals, dimensions and name of the performance indicators.

\begin{tabular}{|c|c|c|}
\hline & \multirow[t]{6}{*}{$\mathrm{F}:$ Finance } & F1 Sales \\
\hline & & F3 Return on assets \\
\hline & & F2 Debt ratio \\
\hline & & F4 Earnings per share \\
\hline & & F6 Return on investments \\
\hline \multirow{14}{*}{ 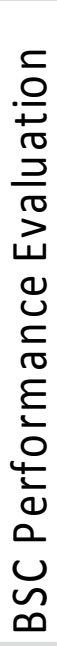 } & & F5 Net profit margin \\
\hline & \multirow{6}{*}{$\mathrm{C}:$ Customer } & C1 Customer satisfaction \\
\hline & & C3 Market share rate \\
\hline & & C2 Profit per customer \\
\hline & & $\mathrm{C} 4$ Customer retention rate \\
\hline & & C6 Profit per customer \\
\hline & & C5 Customer increasing rate \\
\hline & \multirow[t]{6}{*}{ P: Internal Process } & P1 No. of new service items \\
\hline & & P3 Customer complaints \\
\hline & & P2 Transaction efficiency \\
\hline & & P4 Rationalized forms \& processes \\
\hline & & P6 Management performance \\
\hline & & P5 Sales performance \\
\hline & \multirow{5}{*}{ L: Learning and Growth } & L1 Responses of customer service \\
\hline & & L2 Professional training \\
\hline & & L3 Employee stability \\
\hline & & L4 Employee satisfaction \\
\hline & & L5 Organization competence \\
\hline
\end{tabular}

Figure 2. Hierarchical Frameworks of the BSC Performance Evaluation Criteria For Banking

Source: Wu, Tzeng and Chen, 2009

It is mentioned that these evaluation criteria provide bank with improving the performance to the desired level. So, using the model is mostly useful for the banks. Moreover, (Aranda and Arellano, 2010) perform their study on strategic performance measurement systems and managers' understanding of a strategy, so they underline that implementation of Balanced Scorecard changes managers' belief in terms of increasing awareness and importance of the BSC measures. Strategies designed to convert the perspectives of the BSC into action, support the organization's vision and strategy. Within each perspective of the BSC, strategic goals are formed and performance criteria determined to measure if the goals are successful or not. For every performance criteria targets are indicated. Initiatives need to be done to achieve the determined aimed performance (Kaplan and Norton, 1996a: 9). The data for targeted performance used in the Balanced Scorecard can be determined by comparing to competitors. Performance values goals are required to achieve financial objectives, competition to ensure effectiveness, and meet the needs of customers (Horngren, Datar and Foster, 2003: 449-450). When the BSC is applied, real performance of the institute during certain period of time is measured according to the determined indicators in the BSC and it is compared to the targeted performance. Monetary sum or numeral amount achieved at the end of measurement of the each performance indicator appears at the result of the BSC. Also, the minimum base value, maximum limit value and target value of each performance indicator are stated. There is a percentage weight for each perspective in the Balanced Scorecard and total weight sum of all dimensions is equal to $100 \%$. Each performance indicator is evaluated according to the achievement ratio and the target value. Afterwards, result values of the performance indicators are multiplied with the determined percentage weight of each performance indicator.

In addition, one of other important aspects is using the BSC in information technology. As Internet banking is developing, banks are required to develop and implement new strategies. As Venture Bancorp plans to introduce Internet Banking, Venture Bancorp started to use performance reporting to apply its strategy. The bank aims to improve the current Balanced Scorecard system consolidating the relation between the used performance indicators 
in the system. The bank uses a Balanced Scorecard comprising of financial, customer, processes, learning and development dimensions. In the Balanced Scorecard of Venture Bancorp, there are short term performance indicators such as efficiency ratio, asset profitability, net incomes, total asset and asset ratio to the employees. Also, long-term performance indicators for long-term performance measurement presented below exist in the Balanced Scorecard (Frigo, Pustorino \& Krull, 2001):

- $\quad$ Training hours in the strategic subjects;

- $\quad$ Time consumed by the Senior Management to discuss the strategic matters;

- The amount of money spent to invest in electronic network infrastructure to support internet banking;

- The number of marketing activities performed internally and externally;

- $\quad$ Training time spent to introduce internet banking services to the employees;

- Comparison, view and study of competitors' web pages

Also, the following figure shows the Balanced Scorecard of commercial bank and it includes four dimensions of Balanced Scorecard. Each strategic objective is given in parentheses with a cause and effect approach.

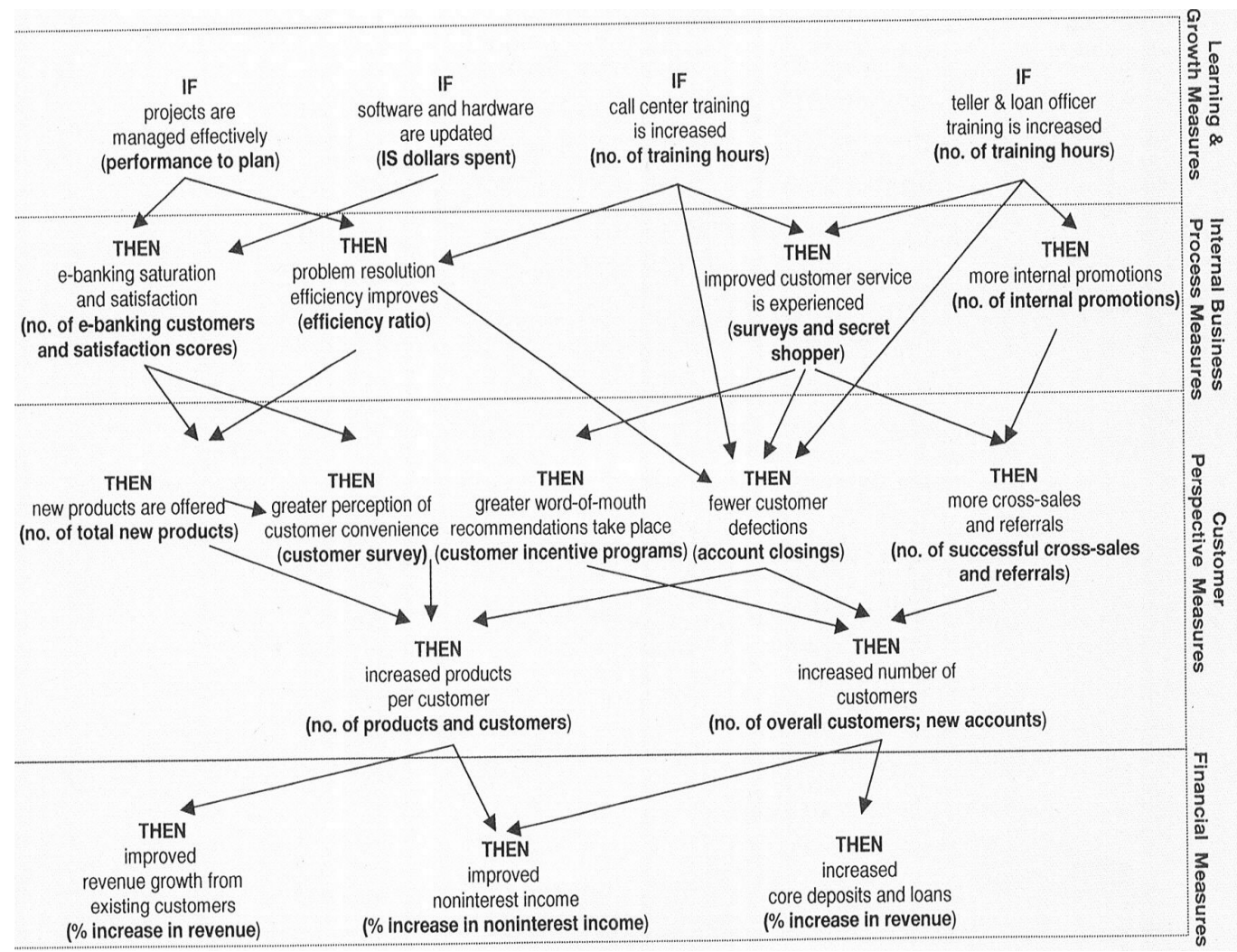

Figure 3. Commercial Bank Balanced Scorecard

Source: Brewer, Davis and Albright, 2005, pp.34.

\section{Conclusion}

Implementation of the method is important as much as its success. For this reason practicing Balanced Scorecard is also important in order to get the desired results in strategic performance measurement. On the other hand, (Kaplan and Norton, 1996b) suggest considering Balanced Scorecard as innovation not just a measure. So, it affects strategic decision making process.

There are nine steps stated in earlier studies for the successful implementation of the BSC. First is assessment of organizations' mission and vision. Secondly, companies evaluate company's strategies in terms of customer's value. Also, objectives of each strategic team are important to reach success. It is also important to create value for the customers with a well-designed strategic map. Additionally, performance measures and initiatives are also important steps to be considered to reach success on implementation of the Balanced Scorecard. 
When the BSC is applied, real performance of the institute during certain period of time is measured according to the determined indicators in the Balanced Scorecard and it is compared with the targeted performance. Monetary sum or numeral amount achieved at the end of measurement of the each performance indicator appears in the result of the BSC. Also, the minimum base value, maximum limit value and target value of each performance indicator are stated. There is a percentage weight for each dimension in the Balanced Scorecard and total weight sum of all dimensions is equal to $100 \%$. Each performance indicator is evaluated according to the achievement ratio and the target value. After that, result values of the performance indicators are multiplied with the determined percentage weight of each performance indicator. In summary, the BSC is a comprehensive approach to provide quality as well as efficiency of financial services. It is important to adopt innovations in banking sector especially for international competitiveness.

\section{References}

Aranda, C., \& Arellano, J. (2010). Consensus and Link Structure in Strategic Performance Measurement Systems: A Field Study. Journal of Management Accounting Research, 22, 271-299. $\mathrm{http}: / / \mathrm{dx}$.doi.org/10.2308/jmar.2010.22.1.271

Aude Deville, Gary D. Ferrier, HervéLeleu. (2014). Measuring The Performance Of Hierarchical Organizations: An Application To Bank Efficiency At The Regional And Branch Levels, Management Accounting Research. http://dx.doi.org/10.1016/j.mar.2013.07.001

Bikker, Joccob. (2010). Measuring Performance of Banks: An Assessment, Journal of Applied Business and Economics Vol. 11(4), De Nederlandsche Bank and Utrecht University

Bolton, R.N. \& Drew, J.H. (1991b). “A Multi Stage Model of Customer's Assessments of Service Quality and Value", Journal of Consumer Research, Vol. 17. http://www.jstor.org/stable/2626833

Brewer, P. C., Davis, S. Ve Albright, T. (2005). "Building A Successful Balanced Scorecard Program", Cost Management, Say1: 1, S.28- 37.

Broady-Preston, J. \& Preston, H. (1999). "Demonstrating Quality in Academic Libraries", New Library World, Vol: 1148, S.124-129. http://dx.doi.org/10.1108/03074809910267518

Carman, J.M. (1990). "Consumer Perceptions of Service Quality: An Assessment of the Servqual Dimensions", Journal of Retailing, Vol. 66.

Coşkun, A. (2005). Performance Measurement in Business, Balanced Scorecard, Istanbul, Istanbul University, Institute Of Social Science, Accounting, Dissertation.

Davis, T.R.V. (1996). "Developing and Employee Balanced Scorecard: Linking Frontline Performance to Corporate Objectives", Management Decision, Vol: 4, S.14-18. http://dx.doi.org/10.1108/00251749610115116

Epstein, M. J. \& Westbrook, R. A. (2001). Linking Action to Profits in Strategic Decision Making. Mit Slone Management Review. Pp. 39-49.

Federico Barnabè, Cristiano Busco. (2012). "The Causal Relationships Between Performance Drivers And Outcomes: Reinforcing Balanced Scorecards' Implementation Through System Dynamics Models", Journal Of Accounting \& Organizational Change, Vol. 8 Iss: 4, Pp.528 - 538. http://dx.doi.org/10.1108/18325911211273518

Firdaus Abdullah, Rosita Suhaimi, GlumaSaban, Jamil Hamali. (2011). "Bank Service Quality (Bsq) Index: An Indicator of Service Performance", International Journal of Quality \& Reliability Management 28 (5): 542 555. http://dx.doi.org/10.1108/02656711111132571

Frigo, M. L., Pustorino, P. G. VeKrull Jr., G. W. (2000). "The Balanced Scorecard for Community Banks: Translating Strategy Into Action", Bank Accounting \& Finance, Vol: 3, S.17-23.

Hanne Nørreklit, Lennart Nørreklit, Falconer Mitchell, TrondBjørnenak. (2012). "The Rise of The Balanced Scorecard! Relevance Regained?" Journal of Accounting \& Organizational Change, Vol. 8 Iss: 4, Pp.490 - 510. http://dx.doi.org/10.1108/18325911211273491

Horngren, C. T., Datar, S. M. \& Foster, G. (2003). Cost Accounting: A Managerial Emphasis, New Jersey, Prentice Hall International.

Hua, A. H., Hsu, C.-W., Kuo, T.-C., \& Wua, W.-C. (2009). Risk Evaluation Of Green Components To Hazardous Substance Using Fmea And Fahp. Expert Systems with Applications, 36, 7142-714. http://dx.doi.org/10.1016/j.eswa.2008.08.031

Hussein A. Hassan Al-Tamimi, HusniCharif. (2011). "Multiple Approaches In Performance Assessment Of Uae Commercial Banks", International Journal Of Islamic And Middle Eastern Finance And Management, Vol. 4 Iss: 1 
Ittner, S. D., Larcker, D. F., \& Meyer, W. M. (2003). Subjectivity and The Weighting Of Performance Measures: Evidence From A Balanced Scorecard. The Accounting Review, 78 (3), $72-758$. http://dx.doi.org/10.2308/accr.2003.78.3.725

José M. Moneva, Eduardo Ortas. (2010). "Corporate Environmental and Financial Performance: A Multivariate Approach", Industrial Management \& $\quad$ Data $\quad$ Systems. $\quad 110(2): \quad 193 \quad-\quad 210$. http://dx.doi.org/10.1016/0883-9026(93)90003-N

Kalle Kraus, Johnny Lind. (2010). The Impact of The Corporate Balanced Scorecard On Corporate Control-A Research Note, Management Accounting Research, Vol. 21, Iss. 4, December 2010, Pages $265-277$. http://dx.doi.org/10.1016/j.mar.2010.08.001

Kaplan, R. S. \& Norton, D. P. (1992). "The Balanced Scorecard - Measures That Drive Performance", Harvard Business Review, Vol: 1.

Kaplan, R. S. \& Norton, D. P. (1996 a). Translating Strategy Into Action: The Balanced Scorecard, Boston, Harvard Business School Press.

Kaplan, R. S. \& Norton, D. P. (1996 b). "Linking The Balanced Scorecard To Strategy", California Management Review, Vol: 1, S.53-79. http://dx.doi.org/10.2307/41165876

Kaplan, R. S. \& Norton, D. P. (2000). "Having Trouble With Your Strategy? Then Map It", Harvard Business Review, Vol: 5, S.167-176.

Kaplan, R. S. \& Norton, D. P. (2004 b). “Plotting Success With 'Strategy Maps”, Optimize, Say1: 2, S.61-64.

Malina, M. A., Nørreklit, H. S. O., \& Selto, F. H. (2007). Relations Among Measures, Climate Of Control, And Performance Measurement Models. Contemporary Accounting Research, 24(3), 935-982. http://dx.doi.org/10.1506/car.24.3.10

Parasuraman, A., Zeithaml, V.A. \& Berry, L.L. (1985). “A Conceptual Model of Service Quality and Its Implications for Future Research”, Journal of Marketing, No. 49, Pp. 41-50. http://dx.doi.org/10.2307/1251430

Parker, C. (2000). "Performance Measurement", Work Study, Vol: 2, S.63-66. http://dx.doi.org/10.1108/00438020010311197

Priscilla S. Wisner, Marc J. Epstein, Richard P. Bagozzi. (2006). Organizational Antecedents And Consequences Of Environmental Performance, In Martin Freedman, BikkiJaggi (Ed.) Environmental Accounting (Advances In Environmental Accounting \& Management, Volume 3), Emerald Group Publishing Limited, Pp.143-167 - See More Http://Www.Emeraldinsight.Com.Elibrary.Fatih.Edu.Tr/Books.Htm?Issn=1479-598\&Volume=3\&Chapterid=17 60960\&Show=Abstract\#Sthash.K72ibj8c.Dpuf

Rigby, D. (2001). "Management Tools and Techniques: A Survey", California Management Review, Vol: 2, S.139-160. http://dx.doi.org/10.2307/41166079

Rigby, D. (2003). Management Tools 2003, Brain \& Company, Www.Bain.Com.

Roland F. Spekléa, Frank H.M. Verbeeten. (2014). The Use Of Performance Measurement Systems In The Public Sector: Effects On Performance, Management Accounting Research, Volume 25, Issue 2, June 2014, Pages 131-146. http://dx.doi.org/10.1016/j.mar.2013.07.004

Rousseau, Y. \& Rousseau, P. (1999). “Turning Strategy Into Action In Financial Services”; Cma Management, Vol: 10, S.25-29.

Salterio, S. (2012). Balancing The Scorecard Through Academic Accounting Research: Opportunity Lost? Journal of Accounting \& Organizational Change, 8(4), 458-476. http://dx.doi.org/10.1108/18325911211273473

Soderberg, M., Kalagnanam, S., Sheehan, N. T., \& Vaidyanathan, G.. (2011). When Is A Balanced Scorecard A Balanced Scorecard?. International Journal of Productivity and Performance Management, 60(7), 688-708. http://dx.doi.org/10.1108/17410401111167780

Tony Davila, Marc J. Epstein, Robert Shelton, Robert D. Shelton. (2006), Wharton School Publication.

Yansheng Zhang, Longyi Li. (2009). Study On Balanced Scorecard Of Commercial Bank In Performance Management System, Proceedings Of The 2009 International Symposium On Web Information Systems And Applications (Wisa'09) Nanchang, P.R. China, May 22-24,2009,Pp.206-209.

YngveAntonsen. (2014). The Downside Of The Balanced Scorecard: A Case Study From Norway, Scandinavian Journal Of Management, Volume 30, Issue 1, March 2014, Pages 40-50. 